J. Perinat. Med. 14 (1986) 219

\section{The concentration of bupivacaine in fetal organs during obstetrical epidural analgesia}

\author{
Wolfgang Müller-Holve', Ludwig v. Meyer ${ }^{2}$, and Peter Nagler ${ }^{2}$
}

${ }^{1}$ Department of Obstetrics and Gynecology, Midwivery School, Klinikum Ingolstadt, and ${ }^{2}$ Institute for Forensic Medicine, University of Munich, Fed. Rep. Germany

\section{Introduction}

Bupivacaine is commonly used for obstetrical epidural analgesia and this agent has been mentioned recently in discussions about complications of this anesthetic method. HUNTER et al [5] reported on fetal accidents during obstetrical epidural analgesia using bupivacaine. Because of reports about a possible increase incidence of hyperbilirubinemia in newborns following delivery under epidural analgesia as well as intoxications in newborns following administration by apparently correct technique [16] caused us to undertake this study. It appeared important to investigate distribution of this local anesthetic agent in the body.

Bupivacaine is a local anesthetic of the amide type. Its molecular weight is 325 . It is a weak base with a $\mathrm{pKa}$ of 8.1. Thus the $\mathrm{pH}$ is important for the degree of dissociation. Bupivacaine has been investigated in numerous studies and has been shown to be of low risk.

Bupivacaine levels have been investigated in plasma as well as whole blood. The ratio of blood to plasma concentration according to TUCKER et al [18] is $0.73 \pm 0.08$. The high protein binding of bupivacaine made it especially appealing as a local anesthetic during pregnancy because of the assumption that this would result in a low placental transfer. More recent investigations by MARX [9] have questioned this advantage of bupivacaine over other local anesthetics because of a decreased plasma protein binding capacity during pregnancy. It cannot be ruled out that more free, and thus active bupivacaine, is present so that under these conditions the risk for complications may not be as low as had been assumed.

\section{Fetal material}

We examined two fetuses following obstetrical epidural anesthesia. Both were born alive.

\section{Fetus $\mathbf{M}$}

Delivery came in the 40th gestational week (39 weeks, 5 days) following induction of labor with oxytocin and prostaglandin $\mathrm{F} 2$ because of the sonographic diagnosis of anencephaly. Induction of labor began at about 5:00 p. m., delivery occurred at 5:00 a. m. Blood samples for the determination of bupivacaine levels were obtained at 7:00 p. m., 8:00 p.m., 8:40 p. m., at birth; $5: 20$ a. m. A total dose of $125 \mathrm{mg}$ bupivacaine was used for the epidural analgesia. The infant breathed immediately and spontaneously, and it died at 21 minutes of age. Autopsy findings: mature fetus with anencephaly, birth weight $2790 \mathrm{~g}$, length $48 \mathrm{~cm}$. Cause of death: postpartum asphyxia. The placenta weighed 700 grams.

\section{Fetus $\mathbf{J}$}

Induction of labor was performed with intra-amniotic prostaglandin F 2 in the 24 th week ( 23 weeks +4 days) because of maternal intestinal carcinoma with lung metastases. The total dose for the epidural analgesia was 
$87.5 \mathrm{mg}$ of bupivacaine. The infant died three minutes after birth. The crownrump length was $29.5 \mathrm{~cm}$ : there were no anomalies.

Organs and blood from these fetuses were frozen and thawed just before the assays. Under these conditions bupivacaine is stable.

\section{Methods}

The samples were analyzed with a Hewlett Packard gas chromatograph 5840 A. A nitrogen sensitive detector was used; and the carrier gas was nitrogen. The analytical limits were $11 \mathrm{ng} /$ $\mathrm{g}$ and $11 \mathrm{ng} / \mathrm{ml}$ in tissue and blood respectively. The concentrations were calculated in the linear range of the calibration curves from 5 to $1000 \mathrm{ng}$ and 50 to $3000 \mathrm{ng}$ respectively. In regard to the reproducability of the method the $\mathrm{V}_{\mathrm{k}}$ was $<8.5 \%$ in the range above $65 \mathrm{ng} / \mathrm{g}$ or $\mathrm{ng} / \mathrm{ml}$ and $\mathrm{a} \mathrm{V}_{\mathrm{k}}$ rate of $8.5 \%-17.9 \%$ below the limit concentration of $65 \mathrm{ng} / \mathrm{g}$ or $\mathrm{ng} / \mathrm{ml}$.

\section{Results}

\subsection{Results from Fetus $M$}

The results are depicted in detail in table I and figure 1. The ratio of fetal to maternal blood levels was 0.37 at the time of birth (ratio of concentrations in umbilical venous blood and maternal blood).

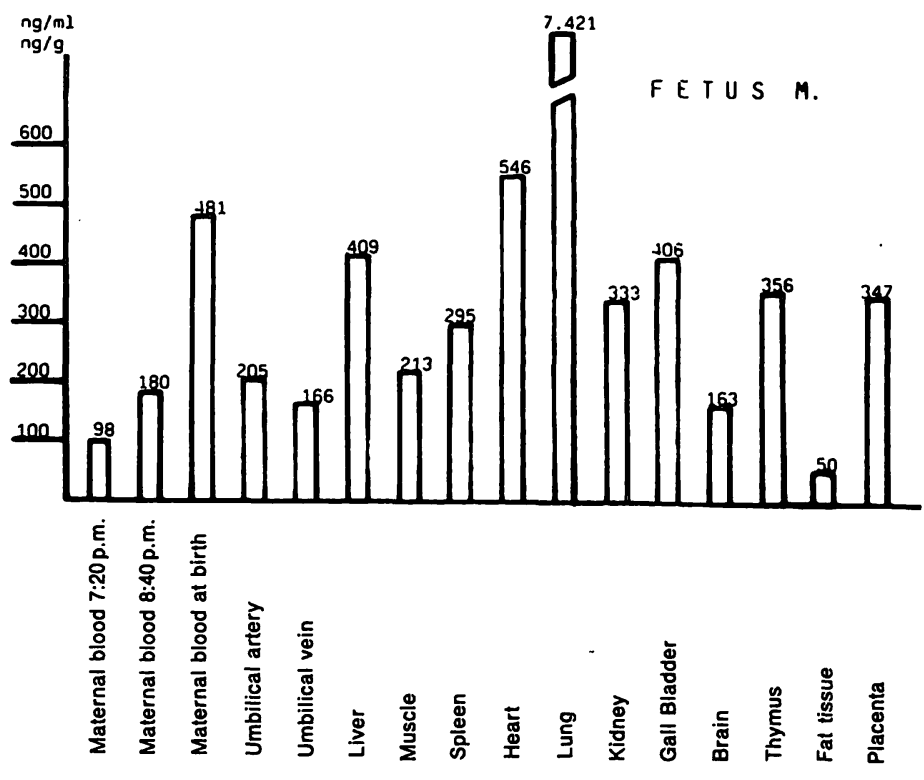

Figure 1. Organ concentration of bupivacaine in Fetus M.
Table I. Distribution of bupivacaine in the tissue in relation to the blood concentration of each fetus.

\begin{tabular}{lll}
\hline & $\begin{array}{l}\text { Tissue } \\
\text { concentration }\end{array}$ & $\begin{array}{l}\text { Ratio of } \\
\text { tissue concentration to } \\
\text { Organ }\end{array}$ \\
$\mathrm{ng} / \mathrm{g}$ or $\mathrm{ng} / \mathrm{ml} l$ & blood concentration \\
\hline
\end{tabular}

Fetus $M$

$\begin{array}{lrr}\text { Blood } & 179 & -- \\ \text { Brain } & 163 & 0.91 \\ \text { Heart } & 546 & 3.05 \\ \text { Lung } & 7421 & 41.46 \\ \text { Liver } & 409 & 2.28 \\ \text { Kidneys } & 333 & 1.86 \\ \text { Spleen } & 295 & 1.65 \\ \text { Gall bladder } & 406 & 2.27 \\ \text { Muscle } & 213 & 1.19 \\ \text { Fat tissue } & 50 & 0.28 \\ \text { Thymus } & 356 & 1.99 \\ \text { Liver fluid } & 229 & 1.28\end{array}$

Fetus J

$\begin{array}{lll}\text { Blood } & 38 & -- \\ \text { Brain } & 42 & 1.11 \\ \text { Heart } & 68 & 1.79 \\ \text { Lung } & 53 & 1.39 \\ \text { Liver } & 97 & 2.55 \\ \text { Kidney } & 57 & 1.50 \\ \text { Spleen } & 68 & 1.79 \\ \text { Gall bladder } & 69 & 1.82 \\ \text { Muscle } & 51 & 1.34 \\ \text { Thymus } & 62 & 1.63\end{array}$

The fetal blood analysis before birth at 8:40 p. m. was $179 \mathrm{ng} / \mathrm{ml}$ with the simultaneous maternal venous concentration at $180 \mathrm{ng} / \mathrm{ml}$. This established the ratio of fetal to maternal blood concentration as nearly 1.0.

The measurements showed a particularly high concentration in the lungs exceeding the concentration of blood by a factor of 40 . Concentration in the heart was three times higher than the blood while concentrations in the liver, kidney, gall bladder and thymus were about double that in the blood. Concentration in fat was low and in muscles only slightly above the blood levels.

\subsection{Results from Fetus $J$}

The results from the organ analysis are shown in table I and figure 2. The liver concentration 


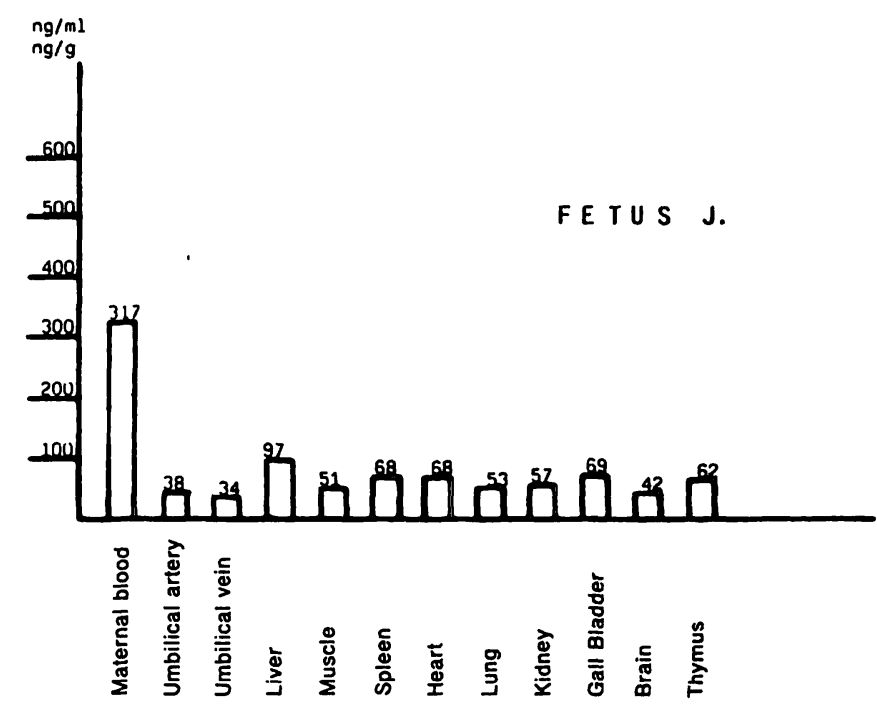

Figure 2. Organ concentration of bupivacaine in Fetus J.

exceeded the blood level $21 / 2$ fold. In the brain the concentration similar to the findings in Fetus $M$ was low at the level of the blood whereas the concentration in the other organs were slightly above that in blood.

\section{Discussion}

Blood levels of bupivacaine found in this study were in ranges found by other authors $[1,12$, 17]. Similarly, the ratio of fetal to maternal concentrations was in the range found by these authors. The distribution of bupivacaine in influenced by the differences between fetal and adult circulation, in that the blood flows from the placenta via the umbilical vein into the fetal body where part of the blood perfuses the liver, with another part flowing through the ductus venosus directly into the vena cava. In the heart the major portion of the blood is directed through the patent foramen ovale into the left atrium. The truncus pulmonalis is perfused predominately with the blood from the vena cava, but only a minor portion flows through the lung, with the major portion entering the aorta via the ductus arteriosus $[10,11,14]$. Thus the lung is poorly perfused being in a side branch of the circulation. In the fetal lamb over $70 \%$ of the entire pulmonary artery flow goes through the ductus arteriosus [11]. Kidney and liver are proportionately less perfused than in the adult [10]. In the mature fetal lamb following the onset of respiration after birth the pulmonary perfusion increases 3 to 10 fold [11] with the pulmonary resistance falling to $1 / 20$ to $1 / 50$ the original value [10]. Frequently the ductus venosus remains patent temporarily after birth, particularly in prematurity, so that the circulation may bypass the liver [11]. These circulatory relationships may explain the difference in the concentrations of bupivacaine in the lungs of Fetus $M$ and J. Fetus $M$ was a mature fetus breathing spontaneously for 20 minutes postpartum; whereas, in Fetus $J$ in the 24th week of gestation no spontaneous respiration occurred. A high organ concentration would require good perfusion. BENOWITZ et al [2] found that after I. V. injection of local anesthetics the lung assumes a sort of buffer function and absorbs up to $75 \%$ of the dose. An important consideration is that the lung takes up the entire output of the right heart, which situation existed in Fetus $M$ following the onset of breathing and the probable closure of the foramen ovale, but not in Fetus J.

In animal experiments SJöSTRAND and WIDMAN [15] in rabbits also found a significantly high concentration of bupivacaine in the lung especially with an acidotic $\mathrm{pH}$. In Fetus $\mathrm{M}$ there are several indicators for the existence of an acidosis: the respiration is stimulated by the rise in partial pressure of $\mathrm{CO}_{2}$ which shifts the acidbase balance towards acidosis [14]. Furthermore it has been known for some time that even in normal deliveries the fetus experiences an increase in acidosis toward the end of labor [13]. In anencephaly additional factors enter: according to LeMIRE [8] in most ancephalic fetuses the lungs are hypoplastic and there is a significant lack of surfactant. This prompts alveolar collapse, pulmonary edema and disturbances in microcirculation. Likewise the cerebral dysfunction of an ancephalic infant promotes acidosis because of disturbed respiratory function. This acidosis in initially metabolic but increasingly in Fetus $M$ became respiratory, i. e., the lung tissue becomes increasingly acid in comparison to blood. 
For technical reasons no blood gas analysis on the fetuses could be carried out and consequently our discussion and conclusions are somewhat limited. The cationic form in which bupivacaine occurs during the initial mild metabolic acidosis primarily leads to its increased binding on the negative charged phospholipids at the surface of the reticuloendothelial cells. During the increasing respiratory acidosis which resulted ultimately in the death of Fetus $M$ from asphyxia an increasing acidity of the intracellular space ensues with a resulting increase in extra/intracellular $\mathrm{pH}$ gradient. This leads to an intracellular accumulation because the intracellular ionized molecule is unable to leave this space. KENNEDY et al [7] have identified this effect. In Fetus $\mathrm{J}$ a different situation prevails. Because the circulation remains de facto in an intrauterine pattern the lung concentration remains correspondingly low. The assumption of an acidosis in Fetus M corresponds with the relatively high level in the myocardium. The strongest stimulus for dilatation of the coronary vessels is hypoxia so that a increased perfusion during asphyxia may be assumed. WIDMAN [19] reported in patients with acidosis and low cardiac output initially high concentrations in the heart which otherwise did not occur. The liver values are only elevated to twice that of the blood levels in both fetuses.

The fetal liver is not yet fully equipped for metabolism of local anesthetics, thus the agent accumulates [3]. Compared with the results of SJösTRAND and WIDMAN [15] our values were noticably lower. Possibly this expresses the lower perfusion in conditions of fetal circulation.

The concentration in the brain is low in both fetuses corresponding with results of SJösTRAND and WIDMAN [15] and is about the same as the blood concentration. SJösTRAND and WIDMAN in their rabbit experiments with normal and acidotic $\mathrm{pH}$ demonstrated that the concentration in the fatty tissue with acidotic $\mathrm{pH}$ was only $40 \%$ of the concentration during normal $\mathrm{pH}$. This is an important factor for the increased blood level during acidosis. Because the fat tissue together with the muscles makes up a good part of the body weight, any decrease in uptake of the local anesthetic into the fat tissue leads to markedly higher blood levels and thus to higher concentrations in the other organs. In Fetus $\mathrm{M}$ the concentration in the fat was low - another indication for acidosis.

The concentration in the kidneys of both fetuses was not different from that in the other organs such as spleen, gall bladder and thymus. In comparison the rabbits, they were distinctly lower. Similar to the assumptions for the liver, the reduced blood flow to these organs during fetal life may play a role. No comparison data are available for spleen, thymus and gall bladder. The concentration in the gall bladder is relatively high, presumably because of the excretion of bupivacaine by the liver into the bile as has been described by other authors $[4,6]$.

The study of Suöstrand and WIDMAN [15] shows that the results were in some areas the same, while they differed in others. Of importance may be that the high values in the lungs of Fetus $M$ corresponds to the values in rabbit lungs with acidotic $\mathrm{pH}$.

On the other hand, it is noteworthy that in both fetuses, liver and kidney concentrations were distinctly lower than reported by SuösTRAND and WIDMAN [15]. This might have its explanation in the different specific anatomical relations in the human fetus. The findings for the concentrations in brain, muscle and fat tissue were largely comparable; for the other organs comparison values were not available.

These results may contribute to better understanding of the metabolic processes when using bupivacaine for obstetric epidural anesthesia. Additional investigations on the role of the lung in the pharmacokinetics of local anesthetics are desirable. For the clinical use of epidural analgesia during delivery, results corroborate further the importance of avoiding fetal acidosis before and during the use of such analgesia. This requires accurate fetal monitoring with cardiotocography and $\mathrm{pH}$ measurements during and after epidural analgesia. 


\section{Summary}

The concentration of bupivacaine in organs of nonviable human fetuses after obstetrical epidural analgesia in customary doses was investigated. The concentrations were determined with a gas chromatograph.

The material consisted of a fetus who died following termination in the 24th week of pregnancy three minutes after birth without spontaneous respiration. The other fetus was born maturely in the 40th pregnancy week with anencephaly who lived 20 minutes following initial spontaneous respiration.

Most noteworthy were the increased concentrations in the liver indicating the important metabolic function of the liver for the metabolism of bupivacaine in the fetus. Further a very high pulmonary concentration was found in the mature fetus. Even though blood gases analysis were not performed we conclude that:

1. the lung is the best perfused organ after birth and onset of spontaneous respiration because of the closure of the ductus arteriosus.

2. because of the increasing agonal respiratory acidosis, bupivacaine accumulates in the lung, the organ from which the acidosis originates. Also, the ionized form the bupivacaine is unable to leave the intracellular space.

For the clinical use of epidural analgesia during delivery, these results constitute an important indication for avoiding fetal acidosis before and during the action of such analgesia. This mandates strict and continuous fetal monitoring. Our results in agreement with other authors show that during fetal acidosis and simultaneous administration of bupivacaine the fetal distress may be potentiated by an accelerated transfer of the anesthetic agent into the fetal placental space. Under normal conditions one may assume that this technique of analgesia has a positive effect on the fetus because of the improved placental perfusion. These results are intended to serve toward an improved understanding of the metabolic processes during the use of bupivacaine for obstetric epidural analgesia. In our opinion the results do not mitigate against the clinical use of epidural analgesia for obstetrical indications.

Keywords: Epidural analgesia, fetal medication, local anesthesia, obstetrical analgesia.

\section{Zusammenfassung}

Die Konzentration von Bupivacain in fetalen Organen bei geburtshilflicher Epiduralanalgesie

Organkonzentrationen von Bupivacain bei nicht lebensfähigen menschlichen Feten nach geburtshilflicher Epiduralanalgesie in üblicher Dosierung wurden untersucht. Die Konzentrationswerte wurden mit Hilfe einer gaschromatographischen Methode gefunden.

Es handelte sich um einen Feten, der nach Abruptio in der 24. Schwangerschaftswoche 3 Minuten post partum verstarb, ohne vorher zu atmen. Außerdem lag ein ausgetragener Fet in der 40. Schwangerschaftswoche mit Anenzephalie vor, der nach Geburt spontan atmete und nach 20 Minuten an seiner Asphyxie verstarb.

An besonders auffälligen Werten sind die erhöhten Leberkonzentrationen beider Feten erwähnenswert: Sie zeigen die wichtige metabolische Funktion der Leber für die Verstoffwechselung von Bupivacain beim Feten an. Außerdem zeigte sich eine sehr hohe Lungenkonzentration von Bupivacain beim ausgetragenen Feten in der 40. Schwangerschaftswoche. Mit einer gewissen Einschränkung wegen des Fehlens von Blutgasanalysen kann aus diesem Ergebnis gefolgert werden:

1. Die Lunge ist das am stärksten durchblutete Organ nach der Geburt durch den Verschluß des Ductus arteriosus nach dem Einsetzen der Spontanatmung.

2. Durch die zunehmende respiratorische Azidose im Finalstadium kommt es zu einer Anreicherung von
Bupivacain in der Lunge, dem Ort der Azidoseentstehung. Hierbei kann die dort ionisierte Form von Bupivacain den intrazellulären Raum nicht mehr verlassen.

Für die klinische Anwendung der Epiduralanalgesie unter der Geburt bedeuten diese Untersuchungsergebnisse einen wichtigen Hinweis zur Vermeidung fetaler Azidosen vor und während der Wirkung einer solchen Analgesieform. Hierfür ist ein striktes kontinuierliches fetales Monitoring indiziert. Unsere Ergebnisse zeigen nämlich auch, daß - in Übereinstimmung mit anderen Autoren - bei Annahme einer fetalen Azidose und gleichzeitiger Applikation von Bupivacain eine Potenzierung der Beeinträchtigung des Feten durch einen Sog des Lokalanaesthetikum in den fetoplazentaren Bereich eintritt. Gleichwohl ist unter normalen Umständen davon auszugehen, da $B$ durch diese Analgesieform eher positive Effekte auf den Feten durch eine verbesserte plazentare Perfusion entstehen. Unsere Untersuchungsergebnisse sollen - neben den dargelegten Hinweisen für das klinische Verhalten - einem besseren Verständnis der Stoffwechselvorgänge bei Anwendung von Bupivacain zur geburtshilflichen Epiduralanalgesie dienen. Eine generelle Kritik an der klinischen Anwendung der Epiduralanalgesie zur geburtshilflichen Schmerztherapie ist unter den genannten Vorbehalten aus unseren Ergebnissen nicht abzuleiten.

Schlüsselwörter: Epiduralanalgesie, fetale Medikamentenbelastung, geburtshilfliche Analgesie, Lokalanästhesie. 


\section{Résumé}

Concentration de bupivacaïne dans les organes fætaux au cours de l'analgésie péridurale en obstétrique

On a déterminé les concentrations de bupivacaïne dans les organes de fœtus humains non viables après analgésie péridurale obstétricale aux doses habituelles. Les concentrations ont été obtenues par chromatographie en phase gazeuse.

Les prélèvements provenaient d'un fœtus décédé trois minutes après la naissance, dans la 24ème semaine de gestation, sans respiration spontanée. L'autre fotus était un anencéphale né à terme, dans la 40ème semaine, qui a vécu 20 minutes après la respiration initiale spontanée. Les concentrations hépatiques augmentées sont les plus remarquables, elles indiquent une importante fonction métabolique du foie pour le métabolisme de la bupivacaïne chez le fœetus. En outre, on a trouvé une concentration pulmonaire très élevée chez le fœtus mature. Et bien que nous n'ayons pas d'analyse des gaz du sang, nous concluons que:

1. Le poumon est l'organe le mieux perfusé après la naissance et le début de la respiration spontanée en raison de la fermeture du canal artériel.

2. En raison de l'accroissement de l'acidose respiratoire agonique, la bupivacaïne s'accumule dans les poumons, organe au niveau duquel l'acidose se produit. Egalement, la forme ionisée de la bupivacaine est incapable de sortir de l'espace intra-cellulaire.

En ce qui concerne l'utilisation clinique de l'analgésie péridurale au cours du travail, ces résultats constituent un argument important pour éviter une acidose fotale avant et pendant l'action d'une telle analgésie. L'analgésie péridurale impose un monitoring fotal strict et continu. Nos résultats en accord avec ceux des autres auteurs montrent qu'au cours d'une acidose fotale avec injection simultanée de bupivacaïne, une souffrance fotale peut être potentialisée par un transfert accéléré de l'agent anesthésique vers l'espace fæto-placentaire. Lorsque les conditions sont normales, on peut supposer que cette technique d'analgésie ait un effet positif sur le fœtus en raison d'une augmentation de la perfusion placentaire. Ces résultats visaient à obtenir une meilleure compréhension des processus métaboliques pendant l'utilisation de bupivacaïne lors de l'analgésie péridurale en obstétrique. Selon nous, les résultats ne vont pas contre l'usage clinique de l'analgésie péridurale pour des indications obstétricales.

Mots-clés: Analgésie obstetricale, analgésie péridurale, anesthésie locale, médication foetale.

\section{References}

[1] Belfrage P, Th RaAbe: Lumbar epidural analgesia with bupivacaine in labor. Am J Obstet Gynecol 121 (1974) 360

[2] Benowitz $\mathrm{N}$ : Lidocaine disposition kinetics in monkey and man. Clin Pharmacol Ther 16 (1974) 87

[3] Finster M, HO Morishima, RN Boyes: The placental transfer of lidocaine and its uptake by fetal tissues. Anesthesiology 36 (1972) 159

[4] Goehl TJ, JB Davenport, MJ Stanley: Distribution, biotransformation and excretion of bupivacaine in the rat and the monkey. Xenobiotica 3 (1973) 761

[5] HuNTER AR, DD MoIR: Confidential enquiry into maternal death. Br J Anaesth 55 (1983) 367

[6] Irestedt L, M ANDreen, P Belfrage: The elimination of bupivacaine after short intravenous infusion in the dog: with special reference to the role played by the liver and lungs. Acta Anaesthiol Scand 22 (1978) 413

[7] KENNEDY RL, A ERENBERG: Effects of changes in maternal-fetal $\mathrm{pH}$ on the transplacental equilibrium of bupivacaine. Anesthesiology 51 (1979) 50

[8] Lemire R: Anencephaly. Raven Press, New York 1978
[9] MARX GF: Cardiopulmonary resuscitation of latepregnant women. Anesthesiology 56 (1982) 156

[10] Moll W, H Bartels: Fetal- und Plazentarkreislauf. In: BAuEReISEN E (ed): Physiologie des Kreislaufs, Band 1: Arteriensystem, Kapillarbett, Organkreisläufe, Fetal- und Plazentarkreislauf. Springer, Berlin 1971

[11] Peltonen T, L Hirvonen: Experimental studies on fetal and neonatal circulation. Acta Paediatr [Suppl] (1965) 161

[12] ReYNolds F, G TAYLOR: Maternal and neonatal blood concentrations of bupivacaine. Anaesthesia 25 (1970) 14

[13] SAling E: Die Blutgasverhältnisse und der SäureBasen-Haushalt des Feten bei ungestörtem Geburtsablauf. Z Geburtshilfe Gynaekol 161 (1964) 262

[14] SCHMidT RF, G Thews: Einführung in die Physiologie des Menschen. Springer, Berlin Heidelberg New York 1976

[15] SJöstrand U, B Widman: Distribution of bupivacaine in the rabbit under normal and acidotic condi-. tions. Acta Anaesthiol Scand [Suppl] 50 (1973)

[16] STEGNER H: Akzidentelle Bupivacain-Intoxikation, eines Neugeborenen, Komplikation einer Kaudal-: anästhesie. Paediatr Prax 24 (1980/81) 605 
[17] Thomas J, CR Climie, LE Mather: The maternal plasma levels and placental transfer of bupivacaine following epidural analgesia. Br J Anaesth 41 (1969) 1035

[18] TUCKER GT, LE MATHER: Pharmacokinetics of local anaesthetics agents. Br J Anaesth 47 (1975) 213

[19] WIDMAN B: Plasma concentration of local anaesthetic agents in regard to absorption, distribution and elimination, with special reference to bupivacaine. Br J Anaesth 47 (1975) 231
Received January 30, 1985. Revised June 21, 1985. Accepted July 9, 1985.

PD Dr. med. Wolfgang Müller-Holve Frauenklinik und Hebammen Lehranstalt Klinikum Ingolstadt 8070 Ingolstadt

Fed. Rep. Germany 